E. B. Gridina, orcid.org/0000-0002-7265-1115, M. L. Rudakov, orcid.org/0000-0001-7428-5318, A. M. Rumiantseva, orcid.org/0000-0002-6686-3437
Saint Petersburg Mining University, Saint Petersburg, Russian Federation, e-mail: Gridina_EB@nuos.pro

\title{
EVALUATION OF STABILITY OF SIDES OF QUARRIES AND DUMPS ON THE BASIS OF A RISK-ORIENTED APPROACH
}

Purpose. The current conditions for open pit mining lead to a number of problems that arise both for domestic and foreign enterprises of the mining complex. In this regard, the aim of the article is to assess the stability of the sides of quarries and dumps based on a risk-based approach.

Methodology. The main research method is a method for analyzing the probability of certain risks, and the method is based on the use of a risk-based approach to assess the risk of collapse in quarries. This approach allows us to assess the stability of the quarry sides and dumps, as well as to select a set of measures to ensure the stability of the array.

Findings. The authors analyzed the existing shortcomings in the regulatory documents related to ensuring the sustainability of quarry sides and dumps. It was found that at the present stage they are not able to effectively ensure the development of internal local documents of enterprises in the field of the occurrence of damage associated with the collapse of rock masses. The data obtained from the construction of the fault tree showed that a comprehensive solution to the problem is needed by attracting a riskbased approach and selecting measures to strengthen the quarry sides and dumps.

Originality. For the first time, the authors applied a preventive risk-based approach to solve the problems with the stability of quarry sides and dumps in a real mountain facility.

Practical value. The results can be used to reduce the level of occupational injuries by reducing or eliminating emergencies associated with caving and landslide phenomena during the operation of an existing quarry.

Keywords: open cast mining, landslide phenomena, mining enterprise, risk-based approach

Introduction. The pace and conditions for the development of open pit mining are associated with ensuring the longterm stability of the quarry and rock-disposal sites during the entire period of development and exploitation of solid mineral deposits. There are acute issues of increasing economic efficiency, industrial safety and environmental friendliness of mining operations [1]. More often, mining conditions are becoming increasingly complex. The number and severity of incidents during mining operations, which have become more frequent in recent years, indicate that the main causes of the most serious accidents at quarries and dumps are caving and landslide phenomena. Modern scientific approaches allow us to classify the stability disturbances of quarries and dumps based on the speed of massif displacement, the slope of the sliding surface, the volume of moving masses and the reasons for their occurrence [2]. Prevention of the development of deformations leading to caving and landslide phenomena, and measures to reduce accident rate at quarries and dumps, is a labor-intensive task that requires serious approaches to its solution $[3,4]$.

The formation of sideboards with elevated angles of inclination allows the mining company to radically increase the efficiency of open-cast mining of mineral deposits by incorporating a significant amount of ore into the open pit contour and generally reducing the cost of overburden operations. However, this increases the probability of deformation of the ledges of the quarry and reduces the safety of mining operations $[5,6]$. When setting the sides of the quarry in steep positions, there is a need to improve methods for stabilizing slopes from their local collapse and shedding, as well as to develop new technical solutions based on them to ensure the safe operation of such sections [7]. The imperfection, and in some cases the lack of a regulatory framework in the Russian Federation in the field of ensuring the stability of slopes of open pits, its discrepancy with world practice in the design engineering and operational activity of open cast mining create unjustified difficulties in the development and approval of project documentation $[8,9]$.

(C) Gridina E. B., Rudakov M. L., Rumiantseva A. M., 2020
Enterprises conducting open-pit mining of minerals create technical documentation in the field of ensuring the stability of slopes of open pits and rock-disposal sites on the basis of the instruction [7], which was developed half a century ago. Field development parameters adopted according to these standards often create contradictions between the efficiency and safety of mining operations. An analysis of the theory and practice of conducting open cast mining proves that the tasks of the technology for forming steep sides with the required protection of equipment and personnel from possible collapse of ledges and landslide phenomena are relevant and not fully resolved.

An important issue is the objective need to develop a modern regulatory document to substantiate the geomechanical stability of sides, benches and disposal sites of quarries. For this, Russian and foreign experience should be generalized, the apparatus of calculation methods expanded, methodological approaches to the implementation of innovative measures and should be defined to ensure safe mining operations.

To illustrate the proposed approach, the conditions of the Russian quarry for the extraction of apatite-nepheline ores are taken as an example. The stability of the sides and ledges of this quarry is determined by the following main factors: fracturing, weathering of rocks, watering of loose Quaternary sediments and destroyed rocks, zone of intense fracturing, methods of drilling and blasting operations on the ultimate contour of the quarry [10]. Analysis of the actual condition of the ledges and sides of the quarry suggests that deformations of various types can develop on the sides of the quarry: scree debris, caving, landslides, splitting, rock-slides, and others. These types of deformations are realized only in the ledges, without violating the stability of the sides as a whole. In this case, the ledges are flattened and the berms are reduced in size. According to the technical documentation, rocks and ores in the near-surface zone of the quarry are highly weathered, disintegrated, and destroyed by various processes, which proves the need for the introduction of techniques for evaluating the stability of quarry sides and disposal dumps, as well as additional means to stabilize the ledges.

A new theory for evaluating the stability of slopes should make it possible to eliminate a number of shortcomings and 
inaccuracies in existing methods of calculation and to develop new ones that will allow one to carry out calculations for almost any mining and geological conditions.

Literature review. To analyze the current situation related to the long-term sustainability of quarry sides, the existing scientific and technical information was carefully analyzed. Scientific papers and articles, as well as patent documentation, written by such authors as: D. V.Zhirov, G.S. Melikhova, V. V. Rybin, V.A. Soharev, S. A. Klimov [6], A. V.Zhabko [3] and many others, give evidence of the variety of information on the subject and only confirm its relevance.

For example, D. V. Zhirov, et al. [6] describe the features of developing deep and super-deep horizons of deposits (which are the most difficult from the standpoint of open cast mining) with early engineering-geological and geomechanical zoning, which makes it possible to improve the accuracy of predicting the risks of impaired stability of structural elements of the quarry, as well as selecting and substantiantig a set of measures for the safe conduct of mining operations. This kind of approach makes it possible for the management of the mining enterprise to evaluate the stability situation in advance and choose risk management methods with the help of competent and timely implementation of relevant measures.

In a similar study A. V. Zhabko [3] examined the main geomechanical problems in open pit mining, which lead the author to the conclusion that there is no alternative method for determining the ultimate equilibrium in evaluating the stability of quarry slopes and the pressing issue of improving the regulatory framework on this matter. Among other things, the author justifies the need to develop a new theory or methodology for assessing the stability of slopes of quarries, which would eliminate a number of shortcomings and inaccuracies in existing calculation methods, since the possibilities of their use in modern mining and geological and technological conditions are clearly limited.

Separately, we should turn our attention to the regulatory documents currently in force when exploiting deposits in an open way in terms of ensuring the stability of slopes of benches, working and non-working sides, as well as slopes of external dumps. In this part, the obvious shortcomings of the regulatory framework in the Russian Federation should be noted as well as its discrepancy with the world practice of design engineering and operational activity of mining deposits in an open way in the field of ensuring the stability of slopes.

For example, the basis of the standards for ensuring technological design in the field of stability of open pits is "Instructions for observing deformations of slopes, high-walls and disposal sites in open pits and developing measures to ensure their stability" (approved by the USSR State Technical Supervision Service on July 21, 1970) [7]. Obviously, the document created more than 50 years ago is no longer able to be regulatory. Designing engineers forced to refer to it are constantly confronted with the real problem of mismatching the actual development conditions, characterized by the great depth and complexity of the ore body, as well as possible aggravating factors: severe climatic conditions of the Far North, and others.

Of course, such documents should be processed and approved accordingly, in particular, and for the purpose of objective control by state bodies. Let us consider the patents in this area. In most cases, they include various technical measures that can be used in case of problems with sustainability that have already occured.

Patent No. 2465404. Authors: V.A. Smirnov, S. V. Tsirel, A.A. Pavlovich, et al. "A method to strengthen slopes of the ledges". This invention relates to the stability of the ledges on the sides of quarries, and in combination with geogrid or geocoatings, it can also be used to strengthen unstable slopes during the construction of roads and railways in mountainous areas in earthquake-prone areas. The method for strengthening the slopes of the ledges includes drilling wells on the upper and lower platforms of the ledges, laying the rope on a slope, an- choring the ends of the ropes in the wells, and tensioning the ropes. As each downhill step is worked out, the tension of the ropes is monitored, according to which additional reinforcement of the uphill benches is made. The technical result consists in increasing the stability of the slopes of the ledges and increasing the safety of mining.

Patent 1343940. Authors: V. F. Zaitsev, Yu. M. Belichenko, A. P. Zharkov and others. "A method to strengthen the side of a quarry". The method for strengthening the side of the quarry includes the excavation of rocks and stage-by-stage strengthening of the formed ledge by piles along its entire height before the mining operations, in order to increase the efficiency of strengthening the side of the quarry with weakened zones and to ensure additional ore mining in these zones; first the rocks of the weakened zone are excavated with the formation of a worked-out space in the upper part of the formed ledge and after reinforcing of the worked-out space with piles, it is filled with reinforced hardening material with the formation of a monolithic plate, which is supported on undisturbed rocks with overlapping of the weakened zone.

This method provides a significant economic effect and allows us to increase the economically acceptable depth of quarries.

A number of foreign patents (for example, US patent No. 4610568, "System and method for stabilizing the slope") offer technical approaches to maintaining the slip zone, in particular, using geogrids with additional anchoring.

In this way, we see that most of the periodical modern publications and patents do not contain global methodological approaches. Basically, these are technical approaches that can be applied either proactively or in case of problems with sustainability.

However, in this area of knowledge there is a much deeper problem - the need to develop methodological approaches in the field of ensuring the sustainability of quarry ledges and disposal sites. From our point of view, it is most rational to lay the basis of the methodology for a risk-based approach that has proven itself, for example, in the field of oil and gas production and transportation.

This approach is described in J.Read and P. Stacey's "Guide to the design of the sides of the quarry" [1], which, in essence, is a summary of modern knowledge in this field. This work is the result of the work of many specialists from many countries of the world. The manual includes 14 chapters, which describe in detail all the work and activities related to the design of quarries from the beginning of development to the liquidation of an enterprise. This book reflects all the best international experience in the design of quarry sides. The work thoroughly reflects even the auxiliary work carried out for the purpose of designing the slopes of quarries, but very little attention is paid to the evaluation of their stability. The main goal of this work - design engineering guidelines - is to provide practitioners involved in the design of open pits with practical tools to ensure the stability of open pits, as well as to deal with the consequences of emergencies due to impaired stability, if possible, without fatalities, injuries and damage to equipment. This research (on the basis of adaptation to specific mining and geological conditions) can be used as a strategic plan of action for the design, construction and ongoing monitoring of quarry ledges.

In this way, the modern regulatory document on ensuring the sustainability of quarry ledges should, in our opinion, be based on a risk-based approach, to the possible implementation of which this work is devoted being carried out for the specific conditions of the Russian mining company.

Purpose. The purpose of the paper is to evaluate the stability of the slopes of quarries and disposal sites based on a riskbased approach.

Research Tasks:

1) to evaluate the stability of the sides of the quarry and disposal sites; 
2) to select a set of measures to ensure the stability of the array;

3) to analyze the shortcomings in regulatory documents related to ensuring the sustainability of quarry sides and dump sites;

4) to select measures to strengthen the sides of the quarry and dump sites.

Research methodology. The method is based on the application of a risk-based approach to assess the risk of collapse in quarries from a monograph [1]. This approach allows us to evaluate the stability of the quarry slopes and dumps, as well as to select a set of measures to ensure the stability of the array.

Risk is a measure of the possible danger, its consequences and the probability of a negative impact on the safety of people, equipment and infrastructure, or the environment. The probability of occurrence and possible consequences are usually used to assess risk. It is noted that risk assessment includes consideration of what could happen if someone is in danger, and the probability of this situation. Risk assessment can help to determine how serious the risk can be, the effectiveness of existing control measures, what actions need to be taken to control, how urgently it is necessary to act.

The results of the analysis of certain risks occurrence probability and their consequences or impacts, as well as the determination of their degrees using the criteria for admissibility or danger, can be presented using a risk matrix. Matrices can be used to demonstrate the results of qualitative and semi-quantitative as well as quantitative risk analyses and determine the degree of risk. In case of disturbance of the side of the quarry, such matrices can be used to display the economic consequences and consequences of certain risks for the security system.

Fig. 1 shows a typical semi-quantitative risk matrix, on which the probability of occurrence of risk is plotted as a percentage along the abscissa axis, and along the ordinate axis, the impact estimated on a five-point scale.

The Table shows a qualitative risk matrix that reflects the consequences of a certain risk for personnel safety. Verbal descriptions establish the degree of consequences and probability, and possible combinations of probability-consequences represent specified qualitative levels of risk and permissibility. The obtained levels of risk and their danger or permissibility are indicated by a certain color: red - high; yellow - medium; green - low risk.

The process of determining the degree of risk consists of comparing the level of risk established in the course of risk
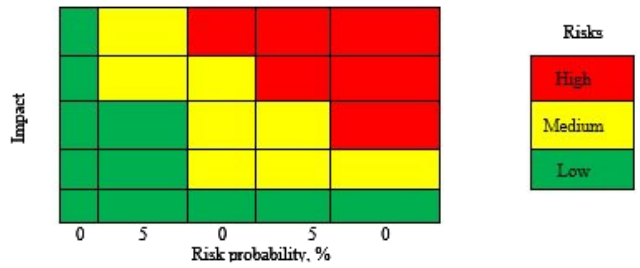

Fig. 1. Semi-quantitative risk matrix

Table

Qualitative risk matrix of personnel safety

\begin{tabular}{|c|c|c|}
\hline \multicolumn{2}{|c|}{ Consequences } \\
\hline Level & Description & Characteristics example \\
\hline 1 & Insignificant & No injuries \\
\hline 2 & Low & First-aid dressing \\
\hline 3 & Medium & Injuries requiring medical attention \\
\hline 4 & High & Extensive injuries / permanent disability \\
\hline 5 & Extreme & Fatal outcome \\
\hline
\end{tabular}

analysis with the risk criteria defined when considering the context of their management. Risks associated with disturbances in the stability of open pit slopes are quantified

$$
R=P o F,
$$

consequences of destructions, where $P o F$ is probability of fracture.

The consequences of the destruction of slopes on the side of a quarry or dump can be broadly divided into 6 main categories:

1. Fatalities and personal injuries, including costs associated with strikes and lawsuits.

2. Damage to equipment and infrastructure, including the cost of replacing equipment and infrastructure.

3. The impact on economic efficiency, dividing the costs by:

- removal of destroyed rock material to ensure safe mining;

- restoration of the slope - it may be necessary to lay out (flatten - decrease the angle of slope) the slope in order to prevent secondary damage due to steeper upper slopes, or use strutting systems;

- repair of haulage routes and provision of repeated access - the exit may be damaged, which may require consideration of the possibility of new access;

- relocation of equipment - it is necessary to compare the costs of equipment downtime in the collapse zone and the costs of moving it to other undisturbed quarry areas where it can be used productively;

- non-recoverable ore - loss of a ramp or part of the slope between ramps can lead to the exclusion of certain parts of the ore body from mining, at least temporarily.

4. Circumstances of insuperable force (the main impact on economic efficiency), which usually should be equated to destruction of the entire slope or medium-term - long-term inability to access ore, which entails non-fulfillment of contracts.

5. A strike or a production conflict, i.e. loss of employee confidence.

6. Public relations, such as stakeholder resistance due to public opinion and/or the environmental consequences of destruction. Intensification of oversight by supervisory bodies.

The consequences of destruction have traditionally been taken into account through cost analysis. However, in the last decade, a risk assessment model was proposed to determine the size of the real consequences of potential damage, allowing the management of the mining company to responsibly assess the degree of acceptable risk.

The risk assessment model underlies the enterprise making decisions related to: determining risks from the point of view of safety and profitability; quantitative risk assessment for various side configurations; quantification of economic gain with a possible increase in risks. The conclusion of the model is that sustainability itself is not the ultimate goal of identifying risks. Fracture of the side slopes is permissible only if the safety of work is ensured without deviating from the design values.

The risk assessment process framework includes four steps:

1. Analysis of the tree of events (faults) allows us to determine the probability of fracture $P o F$ of slope. In this process, a geomechanical task is compiled, in which all the information and uncertainty indicators of the geomechanical model are used. To determine the level of stability of the slope at given input parameters, a traditional stochastic stability analysis is carried out. This analysis reflects the "normal" conditions for the fault tree.

The following analysis is carried out in order to take into account all the uncertainties or errors of the geomechanical model, such as changes/inaccuracies in data regarding geological boundaries (lithological composition and structures crossing the massif), rock mass strength, groundwater levels and rock strength, as well as factors associated with maintaining mining operations, such as overbreak or blasting. The ap- 
proach allows taking into account uncertainties of various levels in the overall assessment of the reliability of the project. Stability analysis is carried out for slopes of ledges and a group of ledges between runaways, as well as the entire side slope [11, 12].

2. Analysis of the event tree identifies risks that may be associated with the fracture of slopes. The probabilities used in the event tree have a subjective assessment based on the use of input data received from mine specialists [13].

3. Risk analysis. The values for the final events are transferred to the event tree to assess the risk of a certain situation (for example, fatal accident, or economic damage) [14].

4. Comparison of the results of the analysis of the data of the top of the fault tree or event tree with the acceptance criteria (risk levels) established by the enterprise management [15].

Results. The method for assessing the probability of fracture $P o F$ or end events is to transform the estimated $P o F$ under normal conditions, taking into account the influence of factors such as uncertainty/error of the given geological boundaries or pore value, using the method of a single assessment of the probability of fracture $(P o F)$ - the probability of an event occurrence (Probability of Occurrence, $\mathrm{PoO}$ ), shown in the figures below. As an illustrative example, we give the option of building a fault tree for two quarry sections. We will call them Situation No. 1 and Situation No. 2.

Situation No. 1. North side of the quarry: sagging of the surface on the upper ledges and the formation of landslide masses on the lower ledges. A system of temporary automobile exits is located on the northern working board of the open pit, which ensures the removal of overburden rock from the working area to dump site No. 5. As a result, an unexpected collapse of the ledges and blockage of the quarry road and mining dump truck occurred.

Consequences for the enterprise:

- personnel injuries requiring first aid, including the costs of strikes and lawsuits;

- damage to equipment and infrastructure, including the cost of replacing equipment and infrastructure;

- the impact on economic efficiency;

- intensification of the control/supervision by the regulative body.

Fig. 2 shows the fault tree and displays the results of its analysis for the first situation.

For the calculation, the probability of fracture $P o F$ under normal operating conditions ( $P o F=0.15$ in Fig. 2) is multiplied by the probability of this occurrence $\mathrm{PoO}(\mathrm{PoO}=0.5$ in Fig. 2). The resulting value of the multiplication of these probabilities is 0.075 . The values of the combined $P o F$ and $P o O$ are calculated for each influencing factor, which are then added up to obtain an overall estimate. Fracture probability calculation example: $P o F=0.15 \cdot 0.5+0.7 \cdot 0.2+0.5 \cdot 0.05+0.6 \cdot 0.2+$ $+0.3 \cdot 0.02+0.5 \cdot 0.05+0.3 \cdot 0.02=0.4(40 \%)$.
The final value of the probability of fracture $P o F$ is $40 \%$, which corresponds to a reliability level of $60 \%$. Subsequent sections are calculated similarly to Situation No. 1.

Situation No. 2. The southern side of the quarry and the nearby dump sites No. 2 and No. 4. Work on dumping and arrangement of a system of stationary translational-loop automobile exits providing opening of working horizons to a finite depth of the valley part, located on a non-working southern side.

Consequences for the enterprise:

- fatalities, extensive injuries/permanent work incapacity of staff, including the costs associated with strikes and lawsuits;

- damage to equipment and infrastructure, including the cost of replacing equipment and infrastructure;

- force majeure circumstances (the main impact on economic efficiency), which entails non-fulfillment of contracts;

- the impact on economic efficiency;

- intensification of the control/supervision by the regulative body.

In Fig. 3. the fault tree is shown and the results of its analysis for the given situation are displayed.

The total value of the probability of fracture $P o F$ is $97 \%$, which corresponds to a reliability level of $3 \%$. To obtain the value of the qualitative risk associated with violations of the stability of the quarry ledges, the consequences of fracture are determined. The consequences of destruction are estimated using probability, which reflects the possibility of their occurrence

$$
P=m / n,
$$

where $m$ is the number of adverse outcomes; $n$ is the number of all outcomes. For the two situations under consideration

$$
\begin{aligned}
& P 1=\frac{m}{n}=\frac{4}{6}=0.67 \\
& P 2=\frac{m}{n}=\frac{5}{6}=0.83 .
\end{aligned}
$$

We get the risk value, which allows us to assess the stability violations of the quarry slopes and dump sites,

$$
\begin{gathered}
R 1=0.4 \cdot 0.67=0.27=27 \% ; \\
R 2=0.971 \cdot 0.83=0.81=81 \% .
\end{gathered}
$$

Based on the results obtained, it is possible to assess the risks for each situation, correlating all the data in the risk matrix in Fig. 1. The performed calculations allow us, guided by the values of the risk probabilities, to propose integrated organizational and technological approaches to improve the situation with the stability of the quarry slopes $[16,17]$.

Situation No. 1: correlating the values of the probability of risk and the impact on personnel, we obtain a low level of risk.

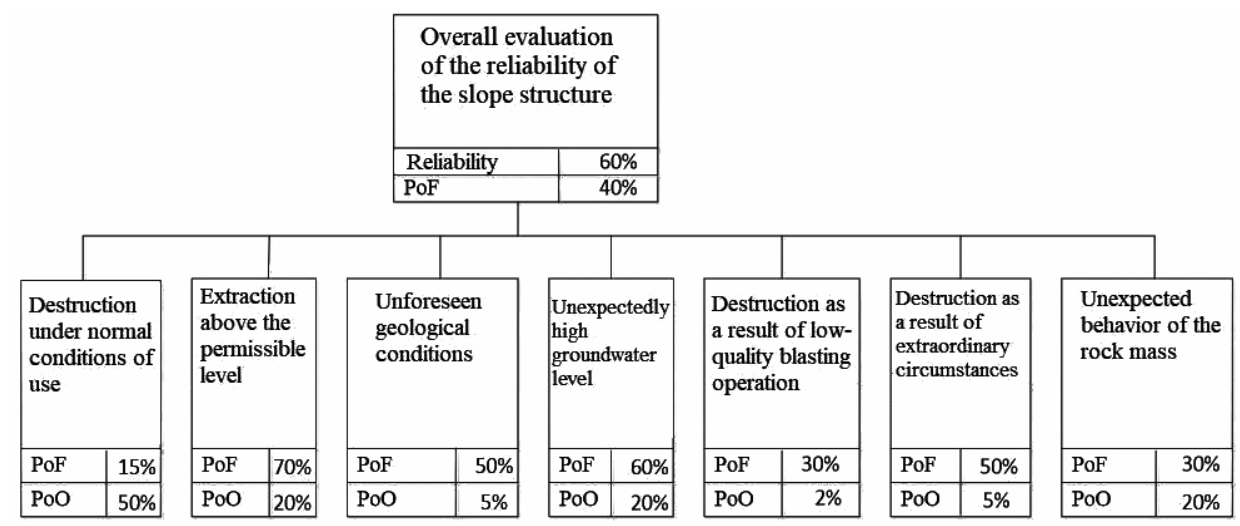

Fig. 2. The result of the analysis of the fault tree for Situation No. 1 


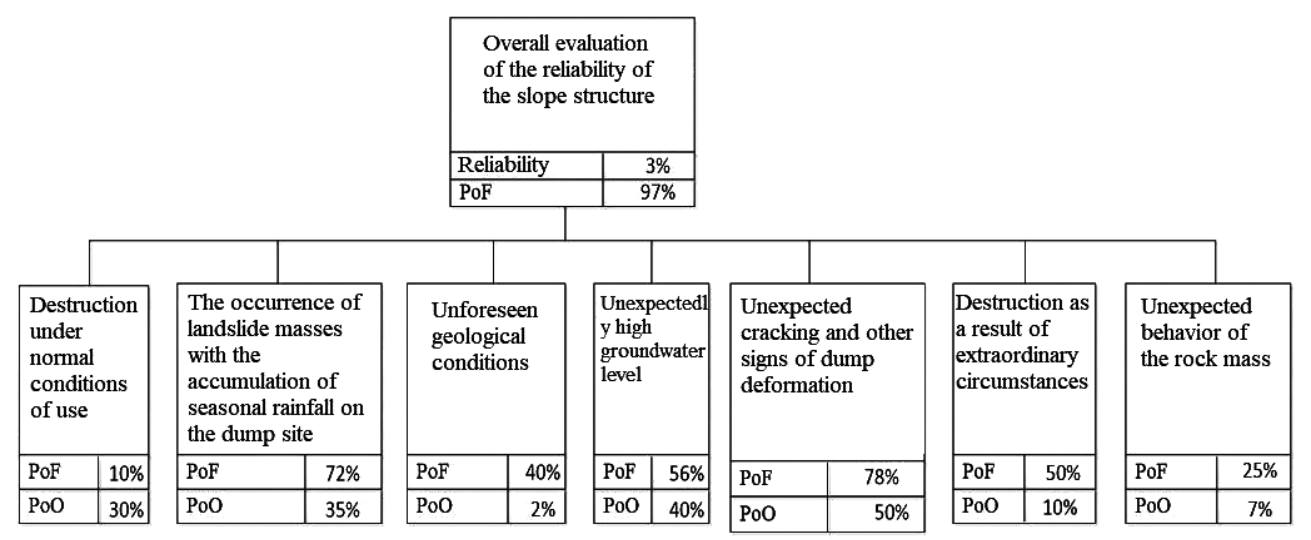

Fig. 3. The result of the analysis of the fault tree for Situation No. 2

With sufficient reliability of the entire side $(60 \%)$, an additional way to increase stability is the use of supports.

Situation No. 2: correlating the values of the probability of risk and the impact on personnel, we obtain a high level of risk. At a high level of risk, for stability of a pit ledges, the fixation of hazardous areas on a non-working south side is suitable, which will prevent the situation that triggers the collapse of dump sites located nearby. To stabilize in this case, it is more efficient to use anchor support systems, improved welded mesh. Dump sites can be further strengthened with cable anchors and tire stacks (alternative to gabions).

Based on the established risk levels, it can be seen that the enterprise may have high risks of various emergencies that could result in loss of human life, loss of expensive equipment, and downtime that will affect the company's income. At the same time, the funds spent on restoring the quarry's working capacity, social payments to the victims, and so on, can be both relatively small and disproportionately high for the mining industry. Thus, the assessment of the stability of open pit sides and dumps using a risk-based approach allows us to apply measures to ensure stabilization in potentially dangerous areas and ensure safe mining operation of the open pit, which will undoubtedly positively affect the economic results of quarry $[1,18]$.

A preventive risk-oriented approach [19] can be used as one of the solutions to the problem of collapses and landslide phenomena, which using expert assessment allows analyzing different sections of quarries and dumping sites, and, as a result, developing complexes of organizational and technological measures to eliminate the potential danger.

Conclusions. Research in the field of stabilization of open quarries and dump sites during open pit mining has shown the possibility of reducing or eliminating emergency situations during the mining operations.

The data obtained from the construction of the fault tree showed that a comprehensive solution to the problem is needed by engaging a risk-based approach and selecting measures to strengthen the ledges of the quarries and dump sites.

Artificial maintenance of the quarry slopes and the dump sites, as well as stabilization tools, will make it possible to strengthen unstable rocks in certain geological conditions, which will reduce the probability of their fracture.

The authors initially analyzed the existing shortcomings in regulatory documents related to ensuring the sustainability of quarry sides and dumps. It has been established that at their present stage they are not able to efficiently ensure the development of internal local documents of enterprises regarding the damage caused by collapse of rock masses, as well as landslide phenomena on the sides of quarries and dump sites in the conditions of significantly increasing depth of modern developments, as well as complicated technological and mining and geological conditions of opencast mining.

Summarizing, it should be noted that the use of a riskbased approach allows us to evaluate in advance the stability of the quarry slopes and rock-disposal sites and give an assessment for their further operation. The set of measures will preserve all the operating characteristics of the quarry and ensure safe operation activity throughout the entire service life, which will positively affect the image of the mining company.

\section{References.}

1. Read, J., \& Stacey, P. (2016). Guide to the design of the sides of the quarry. Yekaterinburg: Pravoved. Retrieved from https:// search.rsl.ru/ru/record/01008545169.

2. Everything about mining (n.d.). Retrieved from http://industry-portal24.ru/.

3. Zhabko, A. V. (2018). About problems and modern methods for assessing the stability of slopes in open cast mining. Proceedings of the USMU, 4(52), 98-107.

4. Zhirov, D. V. (2016). Geotechnical substantiation of decisions on fixing and stabilization of rock massifs in open pits. Mountain Information and Analytical Bulletin, Special Issue “Deep Careers", 164-174.

5. Kharisov, T.F. (2018). Problem of assailment of the safety factor of the open-pit sides. Subsoil User Problems, 3, 108-119. 6. Zhirov, D. V., Melikhova, G. S., Rybin, V. V., Soharev, V. A., \& Klimov, S.A. (2014). Peculiarities of the engineering-geological studies of rock massifs for designing/redesigning deep open pits exemplified with the Kovdor deposit of magnetite and apatite ores. Bulletin of the Kola Science Center, 2, 19-29. 7. Instructions for monitoring the deformation of sides, slopes of ledges and dumps in open pits and the development of measures to ensure their stability (n.d.). Retrieved from https://meganorm. ru/Data2/1/4294853/4294853736.pdf.

8. Rules for ensuring the stability of slopes in coal mines (n.d.). Retrieved from https://meganorm.ru/Index2/1/4293827/4293827109.htm.

9. Order of Rostekhnadzor No. 599 (as amended on $11 / 21 / 2018$ ) "On approval of the Federal norms and rules in the field of industrial safety" Safety rules for mining and processing of solid minerals" (n.d.). Retrieved from http://docs. cntd.ru/document/499066482.

10. Anisimov, A.Yu., Polozhentseva, Yu.S., Zhaglovskaya, A. V., \& Aleksakhin, A. V. (2017). Regional monitoring of staffing support in the coal mining industry. Eurasian Mining, 2, 53-56.

11. Babets, D., Sdvyzhkova, O., Shashenko, O., Kravchenko, K., \& Cabana, E. C. (2019). Implementation of probabilistic approach to rock mass strength estimation while excavating through fault zones. Mining of Mineral Deposits, 13(4), 72-83. 12. Pivniak, H. H., Pilov, P. I., Pashkevych, M. S., \& Shashenko, D. O. (2012). Synchro-mining: Civilized solution of problems of mining regions' sustainable operation. Naukovyi Visnyk Natsionalnoho Hirnychoho Universytetu, (3), 131-138.

13. Sobolev, V., Bilan, N., Dychkovskyi, R., Caseres Cabana, E., \& Smolinski, A. (2020). Reasons for breaking of chemical bonds of gas molecules during movement of explosion 
products in cracks formed in rock mass. International Journal of Mining Science and Technology, 30(2), 265-269.

14. Pavlovich, A.A., Korshunov, V.A., Bazhukov, A.A., \& Melnikov, N. Ya. (2019). Estimation of rock mass strength in open-pit mining. Journal of Mining Institute, 1(239), 502-509. https://doi.org/10.31897/pmi.2019.5.502.

15. Reshetnyak, S.P., Fedotova, Yu. V., \& Savchenko, S. N. (2016). Deep open pit walls design using rock mass stressstrained state. Journal of Mining Institute, 1(197), 169-172.

16. Chebakov, A. V. (2016). Method of calculation stability of the open pit edges. Journal of Mining Institute, 1(185), 175-179. 17. Korshunov, V.A., Solomoichenko, D.A., \& Bazhukov, A.A. (2018). Strength estimation of fractured rock using compression a specimen with spherical indenters. Geomechanics and Geodynamics of Rock Masses: Proceedings of the European Rock Mechanics Symposium (Eurock 2018, Saint-Petersburg, Russia, 22-26 May 2018), vol. 1, (pp. 299-305). London: Taylor and Francis Group. Retrieved from https://app.knovel. com/web/toc.v/cid:kpGGRMV003/viewerType:toc.

18. Omelchuk, M.V., Korotkova, Y.S., \& Vorontsova, E.A. (2019). Estimation of the size of stagnation zones on the territory of the propane-butane tank farm aimed at increasing the safety of the facility. Periodico Tche Quimica, 16(32), 656-667. 19. Kabanov, E. I., Korshunov, G. I., \& Gridina, E. B. (2019). Algorithmic provisions for data processing under spatial analysis of risk of accidents at hazardous production facilities. Naukovyi Visnyk Natsionalnoho Hirnychoho Universytetu, (6), 117-121. https://doi.org/10.29202/nvngu/2019-6/17.

\section{Оцінка стійкості бортів кар'єрів і відвалів на основі ризик-орієнтованого підходу}

\section{О. Б. Грідіна, М. Л. Рудаков, А. М. Румянцева}

Санкт-Петербурзький гірничий університет, м. СанктПетербург, Російська Федерація, e-mail: Gridina_EB@ nuos.pro

Мета. Сучасні умови ведення відкритих гірничих робіт призводять до ряду проблем, що виникають як перед вітчизняними, так і іноземними підприємствами гірничодобувного комплексу. У зв'язку з цим, метою статті є оцінка стійкості бортів кар'єрів і відвалів на основі ризик-орієнтованого підходу.

Методика. Основним методом дослідження є метод аналізу ймовірності настання певних ризиків, також в основі методу пропонується застосування ризик-орієнтованого підходу для оцінки ризику обвалень на кар'єрах. Даний підхід дозволяє оцінити стійкість бортів кар'єру й відвалів, а також підібрати комплекс заходів щодо забезпечення стабільності масиву.

Результати. Авторами були проаналізовані існуючі недоліки в нормативних документах, пов'язаних із забезпеченням стійкості бортів кар'єрів і відвалів. Було встановлено, що вони не здатні на сучасному етапі ефективно забезпечувати розробку внутрішніх локальних документів підприємств в області виникнення руйнувань, пов'язаних з обваленнями масивів гірських порід. Отримані дані побудови дерева відмов показали, що необхідне комплексне вирішення проблеми, шляхом залучення ризик-орієнтованого підходу й підбору заходів зі зміцнення бортів кар'єрів і відвалів.

Наукова новизна. Авторами вперше був застосований превентивний ризик-орієнтований підхід до рішення проблем зі стійкістю бортів кар'єрів і відвалів в умовах реального гірського об'єкта.

Практична значимість. Отримані результати можуть бути використані для зниження рівня виробничого травматизму, шляхом скорочення або виключення аварійних ситуацій, пов'язаних із обваленнями та зсувними явищами, при експлуатації діючого кар'єру.

Ключові слова: відкриті гірничі роботи, зсувні явища, гірничодобувне підприємство, ризик-орієнтований підхід

\section{Оценка устойчивости бортов карьеров и отвалов на основе риск-ориентированного подхода}

\section{Е. Б. Гридина, М. Л. Рудаков, А. М. Румянцеева}

Санкт-Петербургский горный университет, г. СанктПетербург, Российская Федерация, e-mail: Gridina_EB@ nuos.pro

Цель. Современные условия ведения открытых горных работ приводят к ряду проблем, которые возникают как перед отечественными, так и иностранными предприятиями горнодобывающего комплекса. В связи с этим, целью работы является оценка устойчивости бортов карьеров и отвалов на основе риск-ориентированного подхода.

Методика. Основным методом исследования является метод анализа вероятности наступления определенных рисков, также в основе метода предлагается применение риск-ориентированного подхода для оценки риска обрушений на карьерах. Данный подход позволяет оценить устойчивость бортов карьера и отвалов, а также подобрать комплекс мероприятий по обеспечению стабильности массива.

Результаты. Авторами были проанализированы существующие недостатки в нормативных документах, связанных с обеспечением устойчивости бортов карьеров и отвалов. Было установлено, что они не способны на современном этапе эффективно обеспечивать разработку внутренних локальных документов предприятий в области возникновения разрушений, связанных с обрушениями массивов горных пород. Полученные данные построения дерева отказов показали, что необходимо комплексное решение проблемы, путем привлечения риск-ориентированного подхода и подбора мероприятий по укреплению бортов карьеров и отвалов.

Научная новизна. Авторами впервые был применен превентивный риск-ориентированный подход к решению проблем с устойчивостью бортов карьеров и отвалов в условиях реального горного объекта.

Практическая значимость. Полученные результаты могут быть использованы для снижения уровня производственного травматизма, путем сокращения или исключения аварийных ситуаций, связанных с обрушениями и оползневыми явлениями, при эксплуатации действующего карьера.

Ключевые слова: открытые горные работы, оползневые явления, горнодобывающее предприятие, риск-ориентированный подход

Recommended for publication by I. V.Zyryanov, Doctor of Technical Sciences. The manuscript was submitted 18.01.20. 